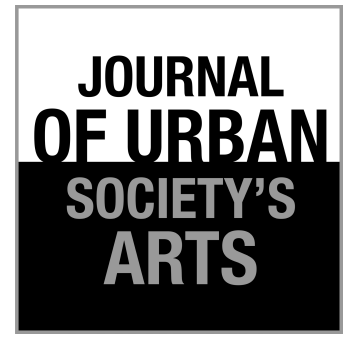

Volume 3 Nomor 2, Oktober 2016: 73-81

\title{
Perwujudan Naskah Drama Anusapati Karya S.H. Mintardja dalam Pementasan Teater
}

Trias Untung Kurniawan

Program Studi Penciptaan Teater

Program Pascaasarjana Institut Seni Indonesia Yogyakarta

Jln. Suryodiningratan No.8, Yogyakarta 55141

Tlp. 082245443219, E-mail: trias.uk@gmail.com

\begin{abstract}
ABSTRAK
Seorang sutradara menentukan kualitas sebuah pementasan teater. Ia dituntut memiliki kepekaan dramatik sehingga dapat menerjemahkan sebuah naskah lakon menjadi pengalaman pentas yang berarti. Naskah lakon menjadi hal yang sangat penting dalam menghasilkan pementasan teater yang berkualitas. Penulis memilih naskah lakon Anusapati karya S.H. Mintardja untuk diwujudkan dalam sebuah pementasan teater. Lakon Anusapati adalah lakon yang tragis, bermula dari kesalahan yang dilakukan Ken Arok untuk mencapai keinginannya merebut kekuasaan. Kesalahan ini mengakibatkan karma yang tidak dapat ditolak oleh Ken Arok dan tujuh keturunannya. Naskah lakon Anusapati akan diwujudkan dalam sebuah pementasan dengan pendekatan ketoprak. Dengan mengawinkan konsep teater modern terhadap perkembangan ketoprak dengan memosisikan sutradara sebagai pusat kontrol atas segala aspek pemanggungan dengan tetap memberi ruang kepada para pemain untuk mengembangkan permainan secara maksimal. Dalam mewujudkan lakon menjadi sebuah pementasan membutuhkan konsep pemanggungan yang dapat dijadikan sebagai arah dalam menjalankan proses kreatif. Konsep pemanggungan memuat pokok-pokok gagasan yang akan diwujudkan dalam pementasan. Garis-garis permainan, desain artistik, dan musik pendukung dirancang untuk memenuhi terwujudnya gagasan. Sutaradara mengorganisasi seluruh aspek pemanggungan yang dikelola oleh beberapa staf artistik, seperti penata pentas, penata busana, penata rias, dan penata artistik sehingga menghasilkan pementasan yang menarik, berkualitas, dan layak untuk ditonton.
\end{abstract}

Kata kunci: lakon Anusapati, S.H. Mintardja, ketoprak

\begin{abstract}
The Embodiment of the Anusapati Script by S.H. Mintardja in Theatrical Staging with the Ketoprak Approach. Director determines the quality of a theatrical production. The Director is required to have dramatic sensibility (sense of dramatic) so that he can translate a script of the play being performed that may experience meaning. The script of the play becomes the thing that is very important in producing the quality of theatrical staging. The script of the play that becomes the choice of the author in a theatrical staging is the Anusapati by SH Mintardja. The Anusapati is a tragic screenplay, it starts from the mistakes done by Ken Arok in accomplishing his desire in seizing power. The mistakes result in karma that cannot be denied by Ken Arok and seven offspring. The script of Anusapati would be performed in a theatrical staging with the ketoprak approach. It is done by combining the concepts on modern theater and the development of ketoprak by positioning the director as the central of controlling over all aspects of staging by keeping on giving the space to the players to develop their performance to the maximum. In realizing the play becomes a staging, it needs the concept of staging that can serve as the creative process in the running direction. The concept of staging contains ideas which will be embodied in the idea of staging. Rules of play, artistic design, and music accompaniment are designed to meet the realization of the idea. The director organizes all aspects of staging that is maintained by some of the artistic
\end{abstract}


staffs, such as a stage manager, a fashion stylist, a make-up stylist, and an artistic director and finally produce an interesting and qualified staging, and worthy to watch.

Keywords: screenplay of Anusapati, S.H. Mintardja, ketoprak

\section{Pendahuluan}

Proses terwujudnya pementasan teater membutuhkan kehadiran seorang pemimpin dan koordinator yang disebut sutradara. Sutradara memimpin dan mengoordinasi proses kreatif seluruh pendukung seperti pemain, penata artistik, dan penata musik. Sutradara bertanggung jawab atas segala hal yang berlangsung di panggung. Seorang sutradara menentukan kualitas sebuah pementasan teater. Sutradara dituntut memiliki kepekaan dramatik sehingga dapat menerjemahkan sebuah naskah menjadi pengalaman pentas yang berarti (Anirun, 2002).

Sutradara dituntut memiliki kecermatan dalam memilih naskah lakon. Naskah lakon yang menarik minat penulis untuk diwujudkan dalam sebuah pementasan teater adalah Anusapati karya S.H. Mintardja. Lakon Anusapati adalah lakon tragis yang banyak menimbulkan kesedihan. Naskah lakon ini mengungkapkan pembunuhan yang tidak berkesudahan sampai tujuh turunan, bermula dari kesalahan yang dilakukan Ken Arok dalam mencapai keinginannya merebut kekuasaan. Kesalahan ini mengakibatkan karma yang tidak dapat ditolak oleh Ken Arok dan tujuh keturunannya.

Terdapat beberapa alasan yang mendasari pemilihan naskah lakon Anusapati karya S.H. Mintardja. Pertama, secara subjektif penulis senang dengan kisah Anusapati. Kisah ini mampu menimbulkan kegelisahan kreatif untuk mewujudkannya menjadi sebuah pementasan teater. Kedua, naskah ini memiliki konflik menarik tentang dendam dan perebutan kekuasaan secara turun-temurun yang selalu berakhir dengan pertumpahan darah. Ketiga, naskah ini memiliki struktur dramatik yang kokoh. Pengaplikasian struktur dramatik dalam naskah lakon Anusapati dapat dilihat dari terjaganya nilai dramatik dari awal sampai akhir. Keempat, naskah ini memiliki kemungkinan bagi para pemain untuk mengembangkan permainannya secara maksimal berdasarkan karakterisasi tokoh yang ada dalam naskah lakon Anusapati.

Tokoh-tokoh dalam naskah lakon Anusapati adalah tokoh-tokoh yang aspek perwatakannya kompleks. Tokoh Sri Rajasa atau Ken Arok, misalnya, adalah sosok raja yang masa lalunya adalah seorang penjahat yang berambisi terhadap kekuasaan. Demikian juga sosok Anusapati, Ken Dedes, dan Tohjaya adalah tokoh-tokoh yang memiliki karakter yang memberi peluang kepada aktor untuk mengembangkan permainannya (Agustina, 2016).

Penulis akan mewujudkan naskah lakon Anusapati dalam sebuah pementasan dengan pendekatan ketoprak. Ketoprak awalnya adalah bentuk pertunjukan yang sederhana. Tumbuh dari masyarakat agraris tradisional yang membutuhkan sarana untuk mengekspresikan berbagai persoalan hidup yang dialami. Kayam (1981: 96) menyebutnya sebagai teater kitsch, yaitu teater yang berorientasi pada kemungkinan perkembangan menjadi "seni massa" yang secara komersial menguntungkan.

Tujuan karya ini adalah untuk mewujudkan naskah lakon Anusapati karya S.H. Mintardja dalam pementasan teater dengan pendekatan

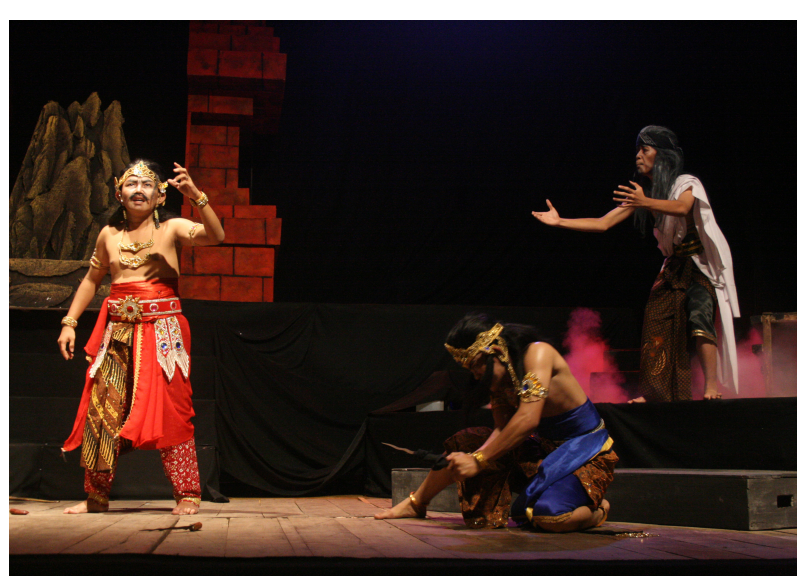

Gambar 1. Salah satu adegan pertemuan Ken Arok dengan Anusapati (Foto: Kurniawan, 2015) 
ketoprak. Selama ini belum ada data tertulis dan dokumentasi pementasan naskah drama Anusapati.

\section{Metode Penelitian}

\section{Metode Penyutradaraan}

Dalam tulisan ini, penulis menggabungkan dua metode penyutradaraan, yakni menurut Gordon Craig dan Laissez Faire. Gordon Craig menempatkan sutradara sebagai pusat penciptaan, sedangkan aktor dan aktris sebagai alat mewujudkan gagasan sutradara. Laissez Faire, sementara itu mengunggkapkan bahwa aktor dan aktris adalah pusat penciptaan. Tugas sutradara adalah membantu aktor dan aktris mengekspresikan dirinya dalam naskah, dan para aktor dan aktris bebas mengembangkan konsepsi individualnya agar melaksanakan peranan sebaik-baiknya (Harymawan, 1988: 65).

Penulis juga mengawinkan konsep teater modern dengan ketoprak, seperti konsep penyutradaraan Bondan Nusantara. Sebagai sutradara, Bondan Nusantara memosisikan diri sebagai pusat kontrol atas segala aspek pemanggungan, tetapi tetap memberi ruang kepada para pemain untuk mengembangkan permainan secara maksimal.

\section{Prosedur Penyutradaraan}

Prosedur penyutradaraan adalah langkah-langkah yang ditempuh sutradara dalam mewujud-kan gagasannya. Prosedur penyutradaraan yang dipakai dalam penelitian ini adalah:

\section{a. Analisis Naskah Lakon}

Analisis naskah lakon meliputi dua hal. Pertama, analisis struktur naskah lakon meliputi analisis tema, penokohan, alur, dan latar peristiwa. Analisis struktur dilakukan untuk memperoleh pemahaman naskah drama secara utuh. Kedua, analisis tekstur naskah lakon yang meliputi dialog, suasana, dan spektakel.

\section{b. Pemilihan Pemain (Casting)}

Kecakapan sutradara dalam memilih pemain sangat memudahkan kerja sutradara dalam mewujudkan tokoh-tokoh dalam pementasan. Pertimbangan lain adalah memilih pemain yang memiliki kedisiplinan dan kesungguhan dalam menjalani proses pementasan.

c. Reading

Reading atau membaca menjadi suatu bentuk latihan awal dalam menyelami tokoh dan mengonstruksikan permainan secara menyeluruh, dan juga sebagai proses pemain mencari dan menemukan aspek ketokohan yang ada dalam naskah lakon.

d. Latihan dan Eksplorasi

Latihan yang dimaksudkan dalam tahap ini adalah latihan yang mengarah pada pembentukan kemampuan pemain melalui latihan-latihan dasar dan latihan teknik seperti olah tubuh, olah vokal, dan olah rasa. Latihan teknik meliputi perkelahian dan permainan senjata. Eksplorasi dalam hal ini adalah upaya mencari bentuk dan gaya permainan yang sesuai dengan naskah drama yang meliputi percobaan-percobaan yang terkait dengan spektakel yang muncul dalam pementasan.

e. Menciptakan Gambar Panggung

Gambar panggung menyangkut seluruh aspek visual yang dapat ditangkap oleh penonton. Termasuk di dalamnya penciptaan artistik, baik itu blocking, movement, garis permainan, pola lantai permainan, maupun centre of interest. Penciptaan gambar, sementara itu terkait dengan artistik yaitu meliputi tata pentas, busana, rias, dan cahaya.

f. Menyatukan Unsur-Unsur Pemanggungan

Tahapan dalam proses ini menyangkut kerja kreatif menyatukan semua unsur, yaitu menyatukan pemain dalam satu kesatuan permainan, menyatukan permainan dengan unsur musik (gamelan), dan menyatukan permainan dengan unsur tata visual.

\section{g. Run Through}

Run trough merupakan suatu tahapan latihan ketika pemanggungan ditampilkan dari awal sampai akhir. Sutradara akan melihat hasil kerja kreatifnya mulai saat layar dibuka sampai layar ditutup kembali.

h. Pertunjukan

Pertunjukan menjadi hasil akhir dari proses kreatif yang sudah dilakukan. Sutradara 
menikmati hasil kerjanya dengan membuat catatan-catatan penting untuk proses selanjutnya.

\section{Perancangan dan Proses Penyutradaraan}

\section{Bentuk dan Gaya}

Secara garis besar lakon terdiri dari tiga bentuk, yaitu tragedi, komedi, dan tragikomedi. Tragedi adalah representasi konflik-konflik para tokoh yang ada dalam masyarakat yang menimbulkan kemalangan dan bencana (Anwar, 2005:8). Pementasan naskan lakon Anusapati digarap dengan pendekatan gaya teater tradisional yaitu ketoprak. Ditinjau dari naskah lakon Anusapati, maka penggunaan gaya ungkap ketoprak adalah pilihan yang tepat.

\section{Peranan Sutradara}

Dalam menyutradari lakon Anusapati, sutradara berperan merancang pementasan dan mewujudkan rancangan pementasan. Peran sebagai perancang pementasan artinya bahwa sutradara membuat desain pemanggungan mulai pemilihan gaya pementasan, menentukan metode penciptaan, membuat rencana pelatihan, sampai garis besar rancangan artistik.

\section{Proses Penyutradaraan}

Proses penyutradaraan Anusapati ini meliputi empat tahap yaitu mencari-cari memberi isi, pengembangan dan pemantapan. Tahap mencari-cari dimulai dari pemilihan pemain, pelatihan pemain, latihan membaca (reading), eksplorasi, dan pembuatan gambar panggung secara garis besar. Tahap memberi isi dalam proses penyutradaraan Anusapati ini adalah mewujudkan garis besar karakter tokoh, menetapkan blocking, dan menetapkan areal permainan sesuai dengan tuntutan naskah. Dalam tahap memberi isi ini, seluruh pemain telah mendapatkan gambaran tentang ruang permainan, garis permainan, komposisi, dan kerja sama antarpemain. Tahap berikutnya adalah tahap pengembangan dan tahap terakhir adalah tahap pemantapan.

Secara rinci proses penyutradaraan yang dilakukan adalah: a. Pemilihan pemain. Ada beberapa cara yang dapat ditempuh sutradara untuk memilih pemain atau rekruitment pemain. Salah satunya adalah membuka kesempatan bagi yang ingin ikut terlibat (Yudiaryani, 2002:387).

b. Latihan membaca (reading). Dalam proses ini dibuka dialog untuk mendapatkan kesepakatan penafsiran. Pemain selanjutnya membaca naskah sesuai dengan peran yang dimainkan. Karakter tokoh dalam naskah lakon dapat diwujudkan secara utuh bila ada pemahaman yang utuh pula terhadap karakter tokoh yang bersangkutan. Latihan membaca ini bisa dilakukan dengan tahap membaca keseluruhan lakon, membaca teks sebagai teks, membaca dengan pemahaman ketika pemain boleh mewujudkan penafsirannya dalam pengucapan dialog, tahap pembentukan yang merupakan tahap akhir dalam proses latihan membaca ketika proses pembacaan sudah dapat dinikmati dan harus mampu memengaruhi emosi pendengar.

c. Pelatihan pemain yang merupakan kesiapan seorang pemain terkait dengan tubuh, suara, dan rasa pemain. Hal ini meliputi latihan olah tubuh, latihan pemanasan, latihan inti olah tubuh, dan yang terakhir pendinginan.

Latihan olah tubuh bertujuan untuk membentuk ketahanan, kelenturan, dan ketangkasan tubuh. Latihan ketangkasan ini diperlukan karena banyak sekali adegan perkelahian yang meliputi latihan kudakuda, menangkis pukulan, membalas serangan dengan tebangan, tangkisan dengan kombinasi tendangan kaki, gerakan dorongan ke samping, menangkis, dan menyerang dengan tendangan kaki. Perkelahian inilah yang dibutuhkan dalam adegan lakon Anusapati.

Latihan olah vokal bertujuan untuk meningkatkan kemampuan pemain dalam memproduksi suara. Suara terwujud dalam dialog-dialog pemain. Latihan vokal dimulai dengan latihan pernafasan yang ditekankan pada pernafasan diafragma. Pemain apabila belum menguasai pernafasan diafragma, 
difokuskan untuk melakukan pernafasan perut. Setelah melakukan latihan pernafasan, latihan berikutnya adalah mengucapkan huruf vokal dan konsonan dengan volume tertentu. Latihan berikutnya adalah latihan mengucapkan kata-kata dan kalimat. Kalimat yang diucapkan adalah kalimat-kalimat yang terdapat dalam naskah lakon Anusapati. Latihan dialog berikutnya difokuskan pada latihan artikulasi, tempo, dan irama pengucapan dialog.

Tahapan berikutnya latihan olah rasa atau disebut juga latihan emosi karena media seorang pemain yang penting selain tubuh dan suara adalah emosi. Emosi menyangkut kompleksitas perasaan yang dimiliki oleh seorang pemain. Latihan dalam hal ini juga terkait dengan konsentrasi dan imajinasi. Pemain apabila telah melakukan latihan konsentrasi, maka berikutnya adalah melatih lima indera pemain. Lima indera meliputi indera penglihatan, pendengaran, penciuman, pengecap, dan peraba. Latihan berikutnya adalah latihan imajinasi. Latihan imajinasi adalah serangkaian latihan menciptakan gambaran-gambaran baru berdasarkan daya asosiasi dan daya khayal.

d. Latihan eksplorasi. Latihan ini dilakukan ketika pemain telah menguasai tokoh yang dimainkan. Eksplorasi dialog bertujuan untuk menemukan karakteristik suara yang mampu menampilkan tokoh secara lebih utuh. Eksplorasi dialog ditekankan pada karakter suara, intonasi, volume, tempo, dan irama dialog. Latihan eksplorasi lain yang dilakukan adalah eksplorasi gerak. Latihan eksplorasi gerak dilakukan setelah latihan olah tubuh. Tubuh dengan demikian siap melakukan gerakan-gerakan sesuai tuntutan eksplorasi. Tokoh Anusapati idealnya memiliki karakter gerak yang berbeda dengan Sri Rajasa. Demikian juga dengan tokoh-tokoh yang lain.

Eksplorasi lain yang penting adalah eksplorasi terhadap ruang. Penjelajahan terhadap ruang berguna untuk menumbuhkan kepekaan dan kesadaran pemain dalam ruang permainan. Ruang permainan adalah ruang yang merepresentasikan latar peristiwa tempat lakon terjadi. Oleh karena itu, ruang menyangkut aspek tempat, waktu, dan suasana. Para pemain berada dalam lingkungan yang harus dihidupkan sesuai tuntutan lakon. Dalam lakon Anusapati, pemain harus menghidupkan ruang paseban, lorong kerajaan, dan taman. Pemain dituntut memiliki imajinasi untuk menghidupkan ruang tersebut. Eksplorasi terhadap ruang juga berfungsi untuk menciptakan visual panggung yang indah. Dalam eksplorasi, pemain diberikan kebebasan dalam menciptakan berbagai kemungkinan komposisi dan garisgaris perpindahan pemain.

e. Penciptaan ruang permainan. Seorang sutradara harus memiliki gambaran yang utuh tentang ruang permainan. Ruang pementasan teater merupakan ruang imajinatif yang menghadirkan suatu kehidupan dalam lakon. Ruang imajinatif adalah ruang rekaan yang diciptakan untuk menghadirkan realitas imajinatif dalam lakon. Sutradara harus mampu menghadirkan ruang sebagai sesuatu yang hidup. Lakon Anusapati pada dasarnya berada dalam suatu ruang yang merepresentasikan sebuah kerajaan. Peristiwa terjadi di sebuah paseban kerajaan Singasari, lorong kerajaan, dan sebuah taman. Sutradara bersama penata pentas membangun ruang tersebut agar mampu merepresentasikan tempat, waktu, dan suasana sebagaimana yang dikehendaki lakon. Pemain juga memiliki gambaran tentang ruang permainan.

f. Blocking. Blockingmerupakan pengorganisasian pemain di atas pentas bertujuan untuk menciptakan gambaran panggung yang baik sehingga memudahkan penonton memahami segala dialog yang diucapkan dengan mengatur komposisi pemain.

Dalam proses penyutradaraan lakon Anusapati, prinsip-prinsip penataan komposisi yang dipakai adalah: (1) komposisi simetris, komposisi yang membagi pemain dalam dua bagian dan menempatkan bagian-bagian tersebut dalam posisi yang benar-benar sama dan seimbang; (2) komposisi asimetris, kom- 
posisi yang tidak membagi pemain dalam dua bagian yang sama persis, tetapi membagi pemain dalam dua bagian atau lebih dengan tujuan memberi penekanan pada bagian tertentu. Komposisi asimetris ini dapat dicapai dengan membagi pemain dalam jumlah yang tidak sama serta posisi yang tidak sama; (3) menciptakan keseimbangan, yaitu pengaturan dan pengelompokan pemain di atas pentas yang ditata sedemikian rupa sehingga tidak menimbulkan ketimpangan. Keseimbangan perlu diperhatikan agar ruang permainan tidak berat sebelah. Terdapatnya ruang kosong, sementara ruang yang lain terisi penuh akan mengakibatkan gambaran yang timpang atau berat sebelah; (4) menciptakan fokus, karena perhatian penonton terhadap sebuah pementasan akan mengarah pada sesuatu yang menarik. Seluruh aktivitas pemain harus dapat ditangkap oleh penonton dengan fokus tertentu. Dalam penggarapan lakon Anusapati, terlihat fokus ditekankan dalam adegan penobatan Anusapati menjadi Pangeran Pati, adegan awal terfokus pada Sri Rajasa sebagai raja Singasari. Saat Sri Rajasa menggelar hiburan berupa tayub, fokus berpindah dalam adegan tayub yang berada di tengah depan. Fokus akan terus berpindah sesuai dengan makna setiap adegan.

g. Menyatukan permainan. Ini dilakukan ketika seluruh unsur telah siap disatukan. Pemain telah mencapai permainan yang prima, blocking telah tertata, tata visual siap dipakai untuk permainan, dan musik pun sudah siap. Setelah semua unsur pementasan siap disatukan, kerja sutradara adalah menjaga keharmonisan dari seluruh unsur pendukung. Sutradara menciptakan dan menjaga satu kesatuan permainan.

\section{Penciptaan Tata Visual dan Tata Musik}

Aspek visual merupakan aspek yang penting dalam membangun latar peristiwa. Tata visual dalam bahasan ini meliputi:

a. Tata pentas yang merupakan penataan atau pengaturan benda-benda mati di atas pentas atau di dalam ruang dan waktu yang berlaku di pentas itu (Padmodarmaya, 1983:4). Tata pentas diharapkan mampu menggambarkan ruang dan waktu sesuai tuntutan lakon Anusapati yang terjadi pada zaman kerajaan Singasari. Peristiwa secara khusus terjadi di sebuah paseban Kerajaan Singasari dan taman di Kerajaan Singasari.

Rancangan tata pentas dibuat dengan pendekatan sugestif-realistis. Menurut Padmodarmaya (1983:106), tata pentas ini menggambarkan kenyataan hidup tidak digambarkan secara lengkap keseluruhan, tetapi hanya diambil kesan-kesan pokoknya saja. Untuk menggambarkan kebutuhan lakon Anusapati, rancangan menghadirkan singgasana Sri Rajasa. Secara visual bentuknya berupa tempat duduk dengan sandaran melengkung. Di belakangnya dibuat gapura untuk menggambarkan suatu kemegahan. Ruang lain yang harus dihadirkan adalah sebuah taman tempat Ken Umang dan taman tempat Ken Dedes. Untuk menggambarkan taman tersebut, rancangan dibuat berupa dua tempat duduk dan dua pilar di taman tempat Ken Umang dan satu tempat duduk dengan satu pilar di taman tempat Ken Dedes. Kedua taman diletakkan di sebelah kanan dan kiri panggung. Taman tempat Ken Umang di sebelah kanan panggung dan taman tempat Ken Dedes berada di sebelah kiri panggung bagian bawah.

b. Tata cahaya yang mengarahkan mata penonton pada suatu gambaran yang wajar dan tidak melelahkan mata. Setiap area yang disinari lampu harus mampu mengungkapkan sesuatu. Setiap area pentas idealnya disinari dengan intensitas, warna, dan sudut datangnya cahaya secara

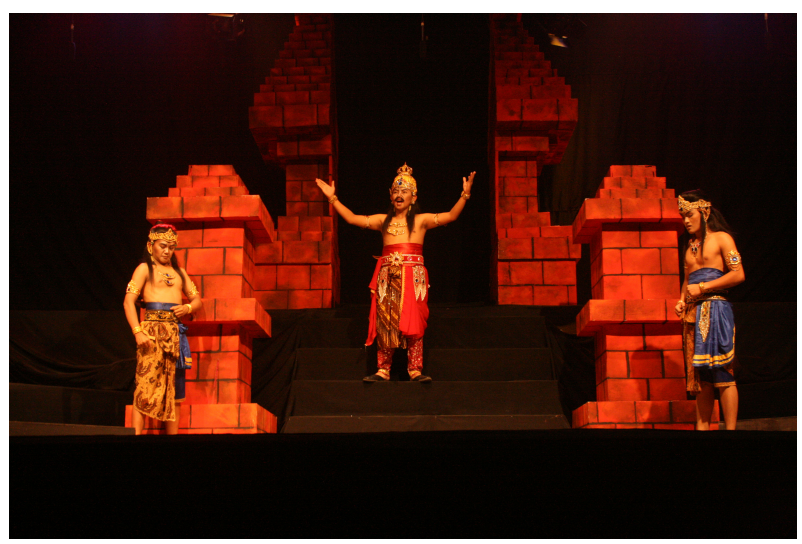

Gambar 2. Tata panggung menggunakan ornamen Candi Bentar khas kerajaan di Jawa TImur (Foto: Kurniawan, 2015) 
berbeda sehingga tercipta bentuk yang kaya. Lakon Anusapati membutuhkan pencahayaan yang mengandalkan pada penciptaan suasana. Selain itu, dibutuhkan pula efek khusus untuk mendukung adegan tertentu. Misalnya, adegan saat munculnya Empu Gandring.

c. Tata busana dengan gambaran tokoh yang meliputi tingkat usia, status sosial, dan lingkungan tempat tokoh berada. Tata busana untuk lakon Anusapati mengambil bentuk busana tradisional Jawa pada masa kerajaan Singasari. Pilihan busana tradisional Jawa adalah pilihan yang tepat.

d. Tata rias secara umum dapat diartikan sebagai seni mengubah penampilan wajah menjadi lebih sempurna. Tata rias untuk lakon Anusapati dibuat untuk mendukung karakter tokoh.

e. Tata musik mengandung empat makna, yakni makna musik yang bertalian dengan ruang dan gerak; makna yang bertalian dengan objekobjek dan aksi-aksi dalam ruang; makna yang bertalian dengan karakter, suasana hati, kondisi, dan emosi; makna-makna yang bertalian dengan

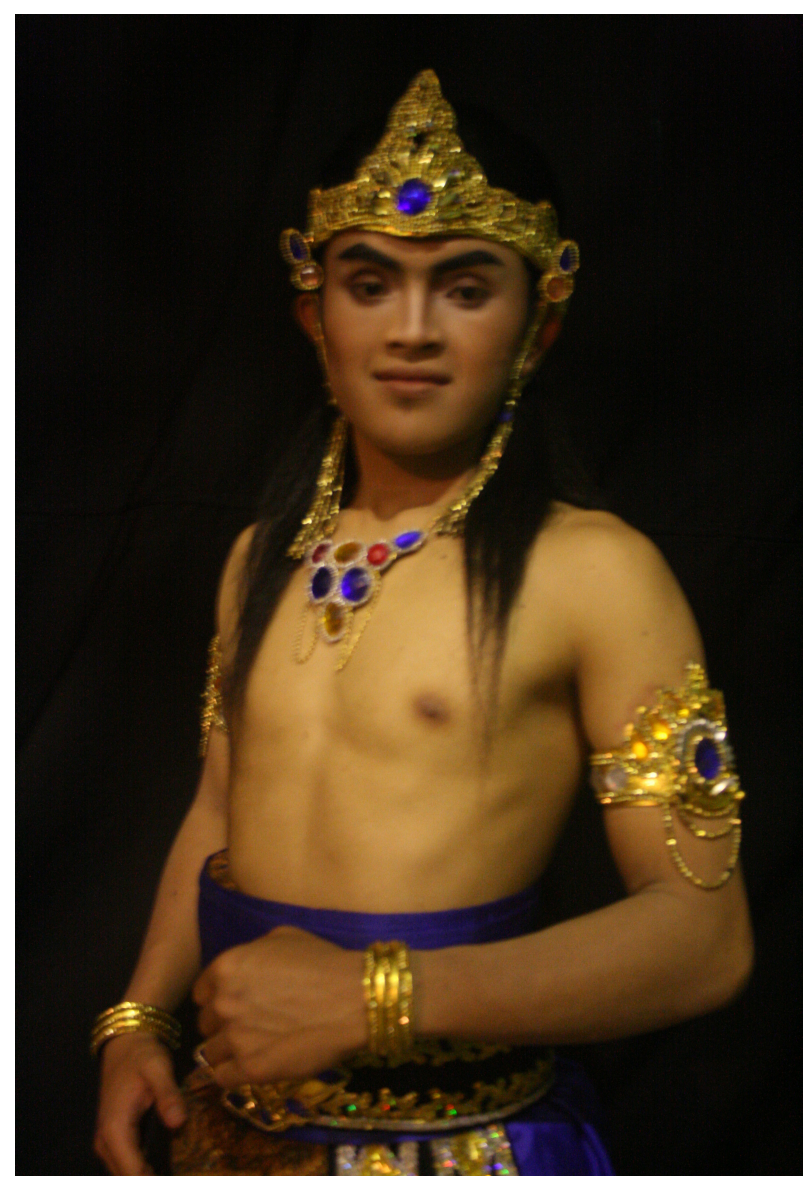

Gambar 3. Anusapati menggunakan busana dan asesoris Jawa jaman Majapahit awal (Foto: Kurniawan, 2015) ide (Waluyo, 2003:118-119). Hal ini menegaskan bahwa musik memiliki peran dalam membangun dramatik suatu lakon. Musik dapat juga membantu pemain dalam menghayati perannya. Musik secara tidak langsung dapat pula mempengaruhi emosi penonton sehingga muncul keterlibatan emosional dengan pementasan yang berlangsung.

Dalam pementasan Anusapati, musik menggu-nakan gamelan Jawa. Pilihan terhadap gamelan Jawa berdasarkan karakter lakon yang menggambarkan kerajaan di Jawa yang bernama Singasari. Konsep pementasan ini mengambil unsur-unsur kesenian ketoprak yang mencerminkan budaya Jawa.

\section{Simpulan}

Pementasan lakon Anuasapati digarap dengan pendekatan teater tradisional ketoprak. Pendekatan ini berdasar lakon yang memiliki latar belakang budaya Jawa dengan segala aspek yang melekat,

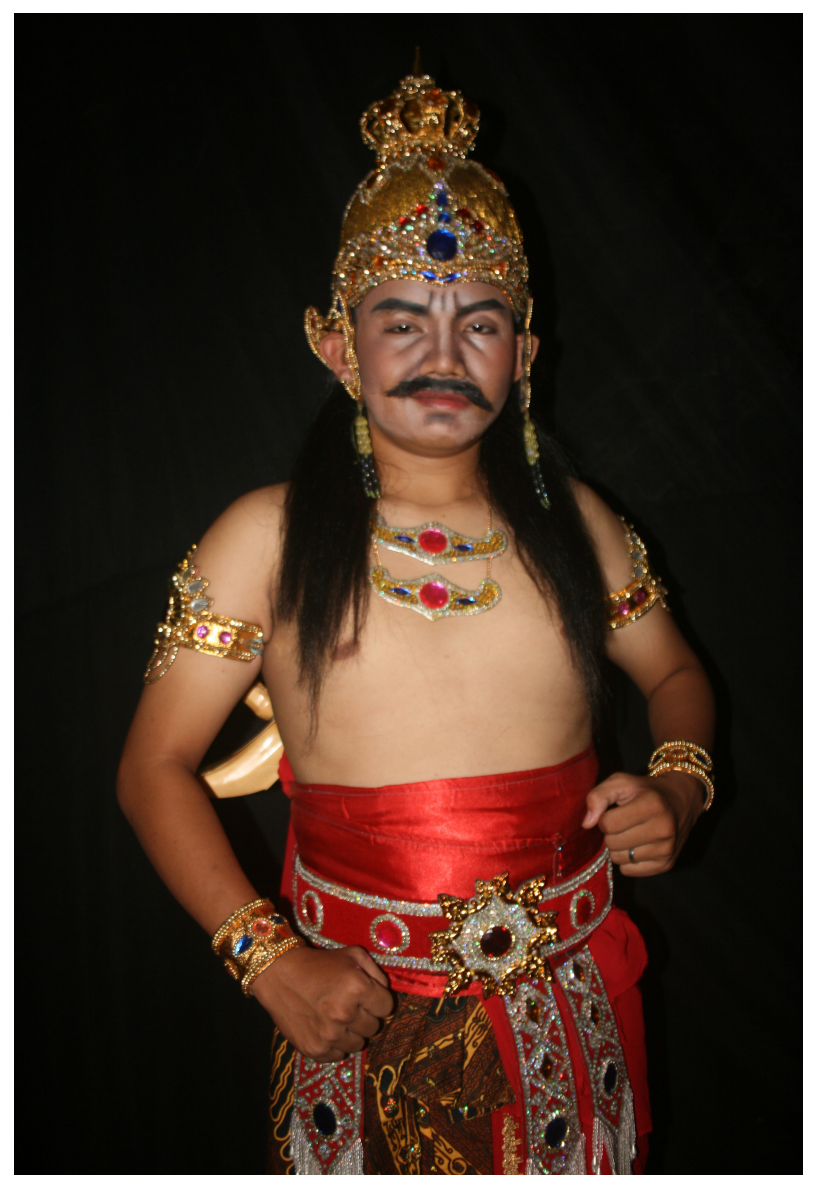

Gambar 4. Ken Arok menggunakan tata rias Raja jaman Majapahit awal (Foto: Kurniawan, 2015) 
seperti latar peristiwa dan alur cerita. Bentuk dan gaya pementasan mengacu pada seni ketoprak. Bentuk dan gaya dengan pendekatan ketoprak akan tampak dalam seluruh aspek pemanggungan, dari aspek pemeranan, tata artistik, sampai pada musik.

Mewujudkan seluruh aspek pemanggungan menjadi tanggung jawab sutradara. Dalam mewujudkan lakon menjadi sebuah pementasan dibutuhkan konsep pemanggungan yang dapat dijadikan sebagai arah dalam menjalankan proses kreatif. Konsep pemanggungan memuat pokokpokok gagasan yang akan diwujudkan dalam pementasan. Garis-garis permainan, desain artistik, dan musik pendukung dirancang untuk memenuhi terwujudnya gagasan. Sutaradara mengorganisasi seluruh aspek pemanggungan yang dikelola oleh beberapa staf artistik, seperti penata pentas, penata busana, penata rias, dan penata artistik.

Pementasan Anusapati pada awalnya dirancang untuk pemain-pemain yang telah memiliki pengalaman dalam pementasan. Pemain-pemain yang telah memiliki pengalaman lebih mudah diarahkan dan lebih mudah mengakomodasi seluruh gagasan sutradara. Akan tetapi, di tengah proses terjadi permasalahan yang memaksa sutradara untuk mengganti pemain. Akhirnya pendukung pementasan Anusapati sebagian besar adalah pemula yang membutuhkan banyak bekal dalam bermain. Sutradara akhirnya harus memulai dengan latihan-latihan dasar yang dibutuhkan oleh pemain pemula.

Seluruh gagasan sutradara belum dapat terwujud secara maksimal. Hal ini menjadi pelajaran yang penting juga bagi seorang sutradara. Pementasan dalam hal ini telah berlangsung dengan lancar. Pementasan telah memberikan pengalaman kepada seluruh pendukung pementasan dan penonton. Sutradara juga mendapatkan pengalaman berharga bahwa mewujudkan gagasan membutuhkan kematangan emosional, kemampuan teknik, dan wawasan yang luas. Hal inilah yang berharga bagi sutradara untuk berkarya lebih baik pada masa mendatang.

Penulis menyarankan untuk penelitian atau sutradara memperhitungkan dengan matang ketika menjatuhkan pilihan pada naskah yang hendak dipentaskan. Kalkulasi tersebut menyangkut per- hitungan terhadap potensi yang dimiliki. Sutradara sebelumnya harus mampu mengukur kemampuannya sendiri sekaligus kemampuan seluruh pendukung pementasan. Kalkulasi yang cermat akan mendukung berhasilnya sebuah pementasan.

Teater merupakan kerja kolektif yang seluruh pendukungnya memiliki peranan penting dalam proses penyutradaraan. Sutradara idealnya tidak memandang dirinya sebagai satu-satunya kekuatan yang menentukan keberhasilan sebuah pementasan. Keberhasilan pementasan ditentukan oleh kemampuan sutradara dalam menyatukan seluruh unsur pembentuk sebuah pementasan teater.

\section{Ucapan Terima Kasih}

Penulis mengucapkan terima kasih kepada: Prof. Dr. Hj. Yudiaryani, M.A.; Suharyoso, M.Sn.; Nanang Arizona, M.Sn.; Dr. Drs. Nur Iswantara, M.Sn.; J. Catur Wibono, M.Sn.; Dr. Untung Muljono, M. Hum, Dosen Etnomusikologi dan penasihat proses pementasan teater Anusapati, Dhani Brain dan Bureg Agus Salim, sahabat penulis dan penasihat Artistik proses pementasan teater Anusapati; Mata Emprit, Penata Artik proses pementasan teater Anusapati; Mbak Rahayu, Mas Aryadi Subagyo dan Ahmad Wiyono, kakak kandung penulis yang telah membantu proses pementasan Anusapati; Ahmad Pitoyo, seniman, dan tokoh masyarakat di Kabupaten Tulungagung; Pak Nurhadi, tokoh sastra di Kabupaten Tulungagung; Drs. Widi Suharto, M.Pd., tokoh sastra dan teater di Kabupaten Tulungagung dan Trenggalek; dan Ki Subagyo, dalang dan tokoh seni di Tulungagung.

\section{Kepustakaan}

Agustina, A. 2016. “Transformasi Naskah Lakon Macbeth (1603-1607) Karya William Shakespeare Ke Film Throne of Blood atau Kumonosu-Jo (1957) Karya Akira Kurosawa". Journal Of Urbarn Society's Arts, 3(1), 1-9. https://doi.org/10.24821

Anirun, S. 2002. Menjadi Sutradara. Bandung: STSI Press. 
Anwar, C. 2005. Drama Bentuk-Gaya dan Aliran. Yogyakarta: Elkaphi.

Harymawan, R. M. A. 1988. Dramaturgi. Bandung: CV Rosda.

Kayam, U. 1981. Seni, Tradisi, Masyarakat. Jakarta: Sinar Harapan.

Padmodarmaya, P. 1983. Tata dan Teknik Pentas. Jakarta: Departemen Pendidikan dan Kebudayaan Direktorat Jenderal Pendidikan Dasar dan Menengah Kejuruan.
Waluyo, H. J. 2003. Drama: Teori dan Pengajarannya. Yogyakarta: Hanindita Graha Widia.

Nyoman Triyanuartha. 2015. "Eksistensi Gula Gending di dalam Budaya Lombok". Journal Of Urbarn Society's Arts, 2(2). https://doi. org/10.24821

Yudiaryani. 2002. Panggung Teater Dunia Perkembangan dan Perubahan Konvensi. Yogyakarta: Pustaka Gondho Suli. 